\title{
Analysis of Difficulties in Enterprise Income Tax Final Settlement
}

\author{
Xiujuan Zhang ${ }^{1, a}$ \\ ${ }^{1}$ School of Economics and Management, Zaozhuang University, Zaozhuang, Shandong Province, \\ China \\ a8932358@qq.com
}

Keywords: Enterprise Income Tax, Final Settlement.

\begin{abstract}
For enterprises, the final settlement of income tax is the most important taxing work which is difficult to adjust, of long duration, and related to multiple tax laws. Especially in recent years, the Ministry of Finance and the State Administration of Taxation have issued a large number of new tax laws and regulations, which further increase the difficulty of enterprise income tax final settlement. Financial personnel in companies need to grasp latest policies and documents, in order to complete the work of final settlement successfully. Based on examples of income tax final settlement in 2016, this paper carries on in-depth analysis on this issue.
\end{abstract}

\section{Introduction}

The time period for final settlement of enterprises' income tax in 2016 is January 1 to May 31 , 2017. Now the work is carried out in enterprises and companies across the country. Compared with previous years, the program of replacing business tax with value-added tax (VAT) has been implemented nationwide since 2016. The Ministry of Finance and the State Administration of Taxation issued a number of latest regulations on taxation such as Notice on Income Tax of Enterprises Contribute Public Equity Donation, (No.45 Document of Finance and Accounting issued in 2016) (hereinafter referred to as No. 45 document, 2016), Notice of Ministry of Finance and the State Administration of Taxation on Perfecting Regulations about Equity Incentive and Income Tax on Technology Investment, (No.101 Document of Finance and Accounting issued in 2016), (hereinafter referred to as No. 101 document, 2016), and Announcement of State Administration of Taxation on Issues about Equity Incentive, and Collection and Management of Income Tax on Technology Investment (No.62 Announcement of State Administration of Taxation issued in 2016) Thus, when calculating final settlement of enterprise income tax, financial personnel are faced with new problems. This paper makes a thorough analysis on these hot and difficult issues, hoping to help these staff.

\section{Tax Treatment on Public Welfare Equity Donation}

The current The Law of the People's Republic of China on Enterprise Income Tax stipulates in article 9 that, in relation to charitable donation payments incurred by enterprises, the portion within $12 \%$ of the total annual profit may be deducted from taxable income. The Implementing Regulations of The Law of the People's Republic of China on Enterprise Income Tax of the People's Republic of China stipulates in article 51 that, public welfare donation refers to donations which the enterprise has contributed to the welfare social organizations or people's governments and relevant administrative departments above county level for public welfare causes as specified in the Law of the People's Republic of China on Donations for Public Welfare. With the development of social economy, the forms of public welfare donation are becoming more and more diverse. In addition to traditional property forms like money, goods and real estates, some corporate also tries to donate equities. So, the Ministry of Finance and the State Administration of Taxation issued No. 45 document, 2016 to make provisions on these cases. Specific regulations go as follows. An enterprises' public welfare donations should be regarded as equity transfer. The income of equity transfer should be determined according to the historical cost, namely the original price when the enterprise bought the equity. The transferred equity refers to shares of other companies, and stocks of listed companies held 
by the enterprise. After equity donation, historical cost of the equity should be used to determine the amount of donation, and deduct the enterprise's income tax in accordance with relevant provisions and tax laws.

The author believes that, the above provisions should be understood from following aspects. Companies' equity capital investment like investment trust funds cannot be regarded as equity transfer. The recipients of donation must be domestic public welfare organizations or communities. These organizations must be non-profit funds, charitable organizations or other kinds of public welfare community groups which are registered in the territory of People's Republic of China, and have the qualification of receiving pre-tax deduction pro bono donations. Typical public welfare organizations include Project Hope Foundation and Song Qing Ling Foundation. If the company donates equity to foreign charitable organizations, the Chinese government or other units, then the company cannot enjoy the preferential policy of tax deduction. The two kinds of equity donation, namely transferring according to fair value, and donating according to fair value measurement, should be treated separately. Different from general equity donation, after public welfare equity donation, the taxable income of the company is calculated in accordance with the historical cost of equity, rather than the market value or fair value of equity. Thus, the taxable income will be 0 . If the company donates shares of unlisted companies, it does not need to pay value-added tax; if the company donates shares of listed companies, it needs to pay VAT. But when calculating the taxable income, this amount shall not be deducted. Similar to other public welfare donations, the portion within $12 \%$ of the total annual profits is permitted to be deducted.

For example: In 2016, A company donated the equity of company B to a public welfare organization registered in the territory of China (the organization has qualification of receiving pre-tax deduction pro bono donations). When A company acquired the equity, the cost was 1 million yuan; the fair value of equity was 1.2 million yuan. The total annual profit of A company was 5 million yuan. We assume that there's no other tax adjustment.

The donation belongs to public welfare equity donation. The income from equity transfer was 1 million yuan, the transfer cost was 1 million yuan, and the transfer income was $1-1=0$ million yuan. Calculating according to the amount of donation, the company's taxable income should not exceed 5 $\times 12 \%=0.6$ million yuan. While the actual income was 1 million, thus, taxable income of $\mathrm{A}$ company was adjusted to 0.4 million yuan.

The taxable income of A company in $2016=5+(1-1)+(1-0.6)=5.4$ million yuan .

If A company donated the equity of company B to a primary school through local government, while other conditions unchanged.

The donation belongs to general welfare donation, rather than public welfare equity donation. The transfer income was 1.2 million yuan, and the transfer cost was 1 million yuan, so the transfer income was $1.2-1=0.2$ million yuan. Calculating according to the amount of donation, the company's taxable income should not exceed $5 \times 12 \%=0.6$ million yuan. While the actual income was 1 million, thus, taxable income of A company was adjusted to 0.4 million yuan.

The taxable income of A company in $2016=5+(1.2-1)+(1-0.6)=5.6$ million yuan.

\section{Tax Treatment on Collective Travel Expenses}

The Implementing Regulations of Law of the People's Republic of China on Enterprise Income Tax stipulates that, for the expenditure which the enterprise has paid as the employee's welfare and for the part not exceeding 14\% of the total employee's salary and wage, it is allowed to be deducted. Notice of The State Administration of Taxation on Enterprise Salaries and Wages and Welfare Expenses Deduction (No.3 Document of National Taxation issued in 2009) (hereinafter referred to as No. 3 document, 2009) stipulates the scope of staff welfare by illustration in article 3.

For enterprises still have social functions, the expenses on facilities, equipment and personnel in internal welfare departments such as staff canteen, bathroom, barber shop, clinic, nursing home and other nurseries are included in employee's welfare expense, including maintenance costs of equipment and facilities, as well as the wages, salaries, social insurance, housing funds and labor 
service fees of welfare department staff. Allowance and non-monetary welfare on health care, housing, transportation and daily life for employees are also included, including allowance on occupational injury, medical allowance for employees who are not covered by medical planning, medical subsidies for direct relatives of employees, heating fee, heatstroke prevention subsidy, hardship subsidy, relief cost, subsidies for staff canteen, travel allowance, etc. Other employee benefits which are in accordance with provisions are also included in employee's welfare expense, including funeral subsidy, pension costs, settling-in allowance, home leave and travelling expenses.

The document does not regulate whether enterprises' expenses on collective travel belong to employee welfare. Thus, many tax authorities, including the State Administration of Taxation, hold that collective travel expense is not a part of expenditure directly related to income, and tax deduction should not be allowed. However, some tax authorities believe that, the document stipulates all welfare expenses related to the health care, living, housing, transportation, other subsidies and non monetary benefits of employees are included in employee welfare. From the point of view of people-oriented spirit, collective travel can reduce working pressure, and has positive influence on improving the life quality and work efficiency of employees, which will further promote the development of the company, and directly increase company income. From this point of view, the costs and expenses of collective travel should be included in welfare benefits of employees, and should be allowed to be deducted in accordance with tax provisions. In addition, we should also know that, the State Administration of Taxation admits that not all kinds of expenses on employee welfare are included in No. 3 document, 2009. Those expenses which are not clearly listed in the document, but are in line with the accrual basis principle and the can meet the requirements of legitimacy, authenticity, relevance, rationality and efficiency of tax deduction, should be regarded as employee welfare expense and calculated in tax deduction.

To sum up, the author holds that, since the State Administration of Taxation has made clear provisions that the expenses on collective travel should not be deducted in enterprises' taxable income, and according to the priority of law at the higher level over that at the lower level, local tax departments should comply with these provisions. But according to the spirit and principles of tax laws, collective travel is conducive to the development of companies, and belongs to expenditure directly related to income, so it should be included in employee welfare, and its expense should be deducted from taxable income (the State Administration of Taxation expressed similar meaning in other informal documents). In order to solve disputes between local tax departments, the State Administration of Taxation need to consider the issue and make clear provisions as soon as possible.

\section{Impact of Replacing Business Tax with Value-added Tax on Final Settlement of Income Tax}

Operating income will decline. Before the replacing business tax with value-added tax, companies in transportation, construction, finance and insurance, service industry and other industries calculated their income on the basis of price including business tax. After replacing, tax is separated with price, and the income is calculated on the basis of tax exclusive price. Thus, enterprises' income will decline.

For example: In 2015, a transportation company paid business tax. The tax rate was $3 \%$, and the annual income was 10 million yuan. When calculating income of 2015, its income was 10 million yuan (including tax), and the business tax was $10 * 3 \%=0.3$ million yuan (can be deducted from taxable income). If the company began to pay VAT in 2016 , the tax rate would be $11 \%$ and the annual income would be 10 million yuan (including tax). When calculating income of 2015, the number was $10 \div(1+11 \%)=9.009$ million yuan (including tax), VAT was $900.9 * 11 \%=0.991$ million yuan (cannot be deducted from taxable income).

The amount of tax deductible will decline. Before the replacing, the business tax of companies from transportation, construction, finance and insurance, service industry and other industries is included in "business tax and additional" item, which can be deducted from taxable income. After the replacing, value-added tax paid by enterprises becomes tax excluded in price, which cannot be 
deducted from taxable income. So the taxable income will increase. In addition, before the replacing, freight costs, rental fees and other expenses can be deducted, too. After the replacing, if the company get VAT special invoice on these expenses, the input VAT will be allowed to be deducted. So the deduction before tax will decrease, and the amount of taxable income will increase.

For example: in 2016, a transport enterprise made profits with VAT of 20 million yuan. The company purchased various assets and paid various fees, obtaining VAT special invoices which represent that the amount of input taxes which can be deducted was 1 million yuan. The output tax of that year was $20 /(1+11 \%) * 11 \%=1.982$ million yuan. The value added tax which cannot be deducted from the income was $1.982-1=0.982$ million yuan. If it was in 2015 , the company should pay business tax $20 * 3 \%=0.6$ million yuan which could be deducted from taxable income. The amount of money spend on purchasing assets and paying costs which could be deducted increase, since the price with value added tax will be recorded. Thus, enterprises' taxable income will increase after the replacing.

Tax basis of purchasing fixed assets will decline. Before replacing business tax with value-added tax, companies in transportation, construction, finance and insurance, service industry and other industries calculated tax on the basis of price including VAT when purchasing fixed assets. After replacing, when these enterprises purchasing fixed assets, if they obtain special VAT invoices, the amount of VAT input will be confirmed, and the tax will be calculated according to price including VAT. Then the depreciation rates of fixed assets will reduce, which cut down the cost and raise taxable income.

For example: in April 2016, a construction company purchased a piece of equipment, and obtained VAT special invoice which shows the price was 1.2 million yuan, the value-added tax was 204 thousand yuan. The expected useful life of the equipment was 10 years, and the estimated ratio of remaining value was $2 \%$. The tax basis of the equipment was 1.2 million yuan, and the depreciation was $1200 *(1-2 \%) /(5 / 12)=49$ thousand yuan. If the business was in 2015 , the depreciation would be $(1200+204) *(1-2 \%) / 10 *(5 / 12)=57.3$ thousand yuan. The depreciation of 2016 reduced 57.3-49=8.3 thousand yuan, while the taxable income increased 8.3 thousand yuan.

\section{Tax Deferral for Enterprises with Technological Investment}

The Implementing Regulations of Law of the People's Republic of China on Enterprise Income Tax stipulates in article 90 that, in one tax year, if the resident enterprise's income from its technology transfer does not exceed 5 million yuan, its enterprise income tax may be exempted; but for the part of its income exceeding 5 million yuan, its enterprise income tax shall be half exempted. In order to encourage technology development and technological achievements transfer, No. 101 Document on Finance and Accounting stipulates that, if an enterprise or an individual holds shares of domestic residents enterprises through technical achievements, and the consideration is stocks or stock rights, the enterprise or individual can pay tax according to current tax policies, or choose tax deferral according to preferential policy. This means that if the investment takes place in 2016, the enterprise or individual may not implement the obligation of tax payment temporarily. When the investment is transferred, the taxable income can be calculated according to the difference between equity transfer income, and the original price of the technological achievements plus reasonable taxes. The company or individual can enjoy the benefits of deferred tax.

For example: in 2016, a company invested through technological achievements, and the tax basis of the achievements was 40 million yuan. The company obtained stock rights, and the fair value of these stocks were 50 million yuan. Then, the company transferred these stocks with the price of 60 million yuan. The company might choose not to pay tax when getting the equity, then the equity transfer would be included in the taxable income, which was $60-40=20$ million. Of course, the company could choose to pay tax when obtaining equity, then the taxable income would be $50-40-5=5$ million. In the future, when the transferring equity, the taxable income would be $50-40=10$ million. But the company cannot enjoy the benefits of deferred tax. 


\section{References}

[1] The Ministry of Finance and the State Administration of Taxation, Notice on Income Tax of Enterprises Contribute Public Equity Donation, (No.45 Document of Finance and Accounting issued in 2016)

[2] Ministry of Finance, the State Administration of Taxation, Notice on Perfecting Regulations about Equity Incentive and Income Tax on Technology Investment, (No.101 Document of Finance and Accounting issued in 2016)

[3] The State Council. Implementing Regulations of The Law of the People's Republic of China on Enterprise Income Tax. 